\title{
The Mastery of Prepositions for and to Among the Sixth Semester Students at English Letters Department of Sanata Dharma University
}

\author{
I Made Alvianto Putra Palamba \& Anna Fitriati \\ madealvian@gmail.com \& fitriati@usd.ac.id \\ English Letters Department, Sanata Dharma University
}

\begin{abstract}
This research aims to measure the mastery of prepositions for and to among the sixth semester students at English Letters Department of Sanata Dharma University. The researcher is also eager to identify whether or not the students find difficulties to decide which prepositions (for or to) they should use in making a correct sentence, especially in translating the Indonesian prepositions untuk, kepada, ke, buat and bagi into English. This will be related to certain conditions in which the students' first language (mother tongue) influences their second language learning. Thus, it is also very important to find out whether or not the students are influenced by their first language (Indonesian) in second language (English) learning process.
\end{abstract}

Keywords: prepositions, errors, mastery, accuracy

\section{Introduction}

Preposition, which links the relationship of a sentence's meaning between the things for which they stand, is categorized as one of the function words. Murcia and Freeman (1999: 402) elaborates that "English prepositions are free morphemes, not bound inflectional affixes as they are in many other languages. The reason that prepositions have the name they do is that they precede nouns-they are pre-positions."

In mastering English as a second or foreign language, a language transfer often happens. It occurs when the second language learners translate the first language into the target language word by word. Indonesian students are the example who learn English as the second language. They still find some difficulties to decide which prepositions they have to use in a sentence, for there are some Indonesian prepositions which share the same meaning but will be different if they are translated into English. It is recognized that the Indonesian students will translate the prepositions for and to into untuk, kepada, ke, buat and bagi. Concurrently, they will have difficulties to translate them into English prepositions for or to and decide which one is appropriate to use because for and to almost have the same meaning if they are translated into Indonesian. In fact, these prepositions are completely different since there are several rules to consider in applying them.

This research focuses on measuring the ability of the sixth semester student at English Letters Department of Sanata Dharma University to apply prepositions for and to, since many students are still not aware about the differences between both prepositions. The students will find difficulties to decide which prepositions they should use in making a correct sentence; whether to use the prepositions for or to especially in translating the Indonesian prepositions untuk, kepada, ke, buat and bagi into English. This will be related to certain conditions in which the students' first language (mother tongue) 
influences their second language learning. Thus, it is also very important to find out whether the students are influenced by their first language (mother tongue) in second language learning process.

The objects of this research are the sixth semester students of the 2015/2016 academic year, in English Letters Department of Sanata Dharma University. The sixth semester students are chosen to be the object of this research because the researcher intends to measure their ability in mastering the English prepositions for and to. Therefore, to get the data, the researcher will conduct a test.

The approach of the study applied in this research is the syntactic approach. According to Guralnik, syntax is the study of the arrangement of words as the elements in a sentence to show their relationship one another (1986: 1444). The syntactic approach is applied because this research deals with the usage of prepositions for and to as the elements to form a correct sentence. Furthermore, this approach is applied to identify the usage of rules of both prepositions in order to build a wellperformed sentence.

\section{Preposition for}

The preposition for is one of the English preposition which is difficult to learn since it often causes some errors in a sentence. Indonesian students who learn English as the second language finds some difficulties whether to use for or to as the appropriate one in a sentence. Compared to the preposition to, for is more confusing because the meaning of for seems abstract, manifold, and elusive (Lindstromberg, 2010: 224). In this research, the researcher provides the function of preposition for according to Oxford Advanced Learner's Dictionary $8^{\text {th }}$ Edition as well. To make a better view of the list of the functions of preposition for, the table is displayed below.

\begin{tabular}{|c|c|c|}
\hline No. & Functions & Examples \\
\hline 1. & $\begin{array}{l}\text { To show who is intended to have or use } \\
\text { something or where something is } \\
\text { intended to be put }\end{array}$ & $\begin{array}{l}\text { - There is a letter for you. } \\
\text { - It is a book for children. } \\
\text { - We got a new table for the dining room. }\end{array}$ \\
\hline 2. & $\begin{array}{l}\text { To express who help } \\
\text { somebody/something }\end{array}$ & $\begin{array}{l}\text { - What can I do for you? } \\
\text { - Can you translate this letter for me? } \\
\text { - Soldiers fight for their country. }\end{array}$ \\
\hline 3. & To concern somebody/something & $\begin{array}{l}\text { - They are anxious for her safety. } \\
\text { - Fortunately for us, the weather changed. }\end{array}$ \\
\hline 4. & $\begin{array}{l}\text { To show someone/something as a } \\
\text { representative }\end{array}$ & - I am speaking for everyone in this department. \\
\hline 5. & To show who is employed (by) & - She is working for IBM. \\
\hline 6. & To reveal the meaning of something & - Shaking your head for "NO" is not universal. \\
\hline 7. & To support somebody/something & $\begin{array}{l}\text { - Are you for or against the proposal? } \\
\text { - They voted for independence in a referendum. } \\
\text { - I'm all for people having fun. }\end{array}$ \\
\hline 8. & To show purpose or function & $\begin{array}{l}\text { - A machine for slicing bread. } \\
\text { - Let's go for a walk. } \\
\text { What did you do that for? }\end{array}$ \\
\hline 9. & To show a reason or cause & $\begin{array}{l}\text { - The town is famous for its cathedral. } \\
\text { - She gave me a watch for my birthday. } \\
\text { - He got an award for bravery. }\end{array}$ \\
\hline 10. & To obtain something & $\begin{array}{l}\text { - He comes to me for advice. } \\
\text { - For more information, call this number. }\end{array}$ \\
\hline 11. & To express an exchange for something & $\begin{array}{l}\text { - Copies are available for two dollars each. } \\
\text { - I'll swap these two bottles for that one. }\end{array}$ \\
\hline
\end{tabular}




\begin{tabular}{|c|c|c|}
\hline 12. & $\begin{array}{l}\text { To consider what can be expected from } \\
\text { somebody/something }\end{array}$ & $\begin{array}{l}\text { - The weather is warm for the time of year. } \\
\text { - She's tall for her age. } \\
\text { - That's too much responsibility for a child. }\end{array}$ \\
\hline 13. & $\begin{array}{l}\text { To express the better, happier, etc. } \\
\text { feeling of something }\end{array}$ & - You'll feel better for a good night's sleep. \\
\hline 14. & $\begin{array}{l}\text { To show where somebody/something is } \\
\text { going }\end{array}$ & $\begin{array}{l}\text { - Is this the bus for Chicago? } \\
\text { - } \quad \text { She knew she is destined for a great future. }\end{array}$ \\
\hline 15. & To show a length of time & $\begin{array}{l}\text { - I'm going away for a few days. } \\
\text { - That's all the news there is for now. }\end{array}$ \\
\hline 16. & $\begin{array}{l}\text { To show that something is arranged or } \\
\text { intended to happen at a particular time }\end{array}$ & $\begin{array}{l}\text { - An appointment for May } 12 \\
\text { - We're invited for } 7.30 \text {. }\end{array}$ \\
\hline 17. & $\begin{array}{l}\text { To show how difficult, necessary, } \\
\text { pleasant, etc. something is that } \\
\text { somebody might do or has done }\end{array}$ & $\begin{array}{l}\text { - It's useless for us to continue. } \\
\text { - There's no need for you to go. } \\
\text { - For her to have survived such an ordeal is } \\
\text { remarkable. } \\
\text { - The box is too heavy for me to lift. } \\
\text { - Is it clear enough for you to read? }\end{array}$ \\
\hline 18. & $\begin{array}{l}\text { To show who can or should do } \\
\text { something }\end{array}$ & $\begin{array}{l}\text { - It's not for me to say why he left. } \\
\text { - How to spend the money is for you to decide. }\end{array}$ \\
\hline
\end{tabular}

\section{Preposition to}

As a preposition, the basic spatial meaning of to is used to express certain verbs of giving and sending such as transmit, forward, (re)direct, communicate, distribute, transfer, grant, etc. - as well as with verbs of intended or potential giving or sending such as allot and assign (Lindstromberg, 2010: 233).
Moreover, according to Close (1975: 166), the preposition to expresses relationship in space. To make a better understanding of the use of preposition to, the researcher provides the functions of preposition to along with the examples of each function according to Oxford Advanced Learner's Dictionary 8th Edition as follows.

\begin{tabular}{|c|c|c|}
\hline No. & Functions & Examples \\
\hline 1. & $\begin{array}{l}\text { To show the direction of something; } \\
\text { towards something }\end{array}$ & $\begin{array}{l}\text { - I walked to the office. } \\
\text { - He's going to Paris. } \\
\text { - It is my first visit to Africa. } \\
\text { - He pointed to something on the opposite bank. }\end{array}$ \\
\hline 2. & $\begin{array}{l}\text { (to) the something (of something) } \\
\text { located in the direction mentioned from } \\
\text { something }\end{array}$ & $\begin{array}{l}\text { - Place the cursor to the left of the first word. } \\
\text { - There are mountains to the north. }\end{array}$ \\
\hline 3. & $\begin{array}{l}\text { To show something is as far as } \\
\text { something }\end{array}$ & $\begin{array}{l}\text { - The meadows lead down to the river. } \\
\text { - Her hair fell to her waist. }\end{array}$ \\
\hline 4. & To reach a particular state & $\begin{array}{l}\text { - The vegetables are cooked to perfection. } \\
\text { - } \quad \text { The letter reduced her to tears }\end{array}$ \\
\hline 5. & $\begin{array}{l}\text { To show the end or limit of a range or } \\
\text { period of time }\end{array}$ & $\begin{array}{l}\text { - A drop in profits from } \$ 105 \text { million to around } \\
\$ 75 \text { million. } \\
\text { - I like all kinds of music from opera to reggae. } \\
\text { - I watched the programs from the beginning to } \\
\text { end. }\end{array}$ \\
\hline 6. & $\begin{array}{l}\text { To show (something) before the start of } \\
\text { something }\end{array}$ & $\begin{array}{l}\text { - How long is it to lunch? } \\
\text { - It's five to ten (= five minutes before ten o'clock). }\end{array}$ \\
\hline 7. & $\begin{array}{l}\text { To show the person or thing that } \\
\text { receives something }\end{array}$ & $\begin{array}{l}\text { - He gave it to his sister. } \\
\text { - I will explain to you where everything goes. }\end{array}$ \\
\hline
\end{tabular}




\begin{tabular}{|c|c|c|}
\hline & & $\begin{array}{l}\text { - I am deeply grateful to my parents. } \\
\text { - } \quad \text { To whom did she address the letter? }\end{array}$ \\
\hline 8. & $\begin{array}{l}\text { To show the person or thing that is } \\
\text { affected by an action }\end{array}$ & $\begin{array}{l}\text { - She is devoted to her family. } \\
\text { - What have you done to your hair? }\end{array}$ \\
\hline 9. & $\begin{array}{l}\text { To show that two things are attached } \\
\text { or connected }\end{array}$ & - Attach this rope to front of the car. \\
\hline 10. & $\begin{array}{l}\text { To show a relationship between one } \\
\text { person or thing and another }\end{array}$ & $\begin{array}{l}\text { - } \quad \text { She is married to an Italian. } \\
\text { - } \quad \text { The key to the door. } \\
\text { - } \quad \text { The solution to this problem. }\end{array}$ \\
\hline 11. & $\begin{array}{l}\text { To show something is directed toward; } \\
\text { concerning }\end{array}$ & $\begin{array}{l}\text { - It is a threat to world peace. } \\
\text { - } \quad \text { She made a reference to her recent book. }\end{array}$ \\
\hline 12. & $\begin{array}{l}\text { To introduce the second part of a } \\
\text { comparison or ratio }\end{array}$ & $\begin{array}{l}\text { - I prefer walking to climbing. } \\
\text { - } \quad \text { The industry today is nothing to what it once is. }\end{array}$ \\
\hline 13. & To show a quantity or rate & $\begin{array}{l}\text { - There are } 2.54 \text { centimeters to an inch. } \\
\text { - This car does } 30 \text { miles to the gallon. }\end{array}$ \\
\hline 14. & $\begin{array}{l}\text { To show an honor towards } \\
\text { somebody/something }\end{array}$ & $\begin{array}{l}\text { - A monument to the soldiers who died in the war. } \\
\text { - Let's drink to Julia and her new job. }\end{array}$ \\
\hline 15. & $\begin{array}{l}\text { To show something happens while } \\
\text { something else is happening or being } \\
\text { done. }\end{array}$ & - He left the stage to prolonged applause. \\
\hline 16. & $\begin{array}{l}\text { To show somebody's attitude or } \\
\text { reaction to something }\end{array}$ & $\begin{array}{l}\text { - His music is not really to my taste. } \\
\text { - } \quad \text { To her astonishment, he smiled. }\end{array}$ \\
\hline 17. & $\begin{array}{l}\text { To show what somebody's opinion or } \\
\text { feeling about something is }\end{array}$ & - It sounded like crying to me. \\
\hline
\end{tabular}

\section{Indonesian Preposition untuk}

Chaer states that the preposition untuk is used to reveal "aim" or "intended action" which precedes pronoun, as in (a) Beliau membawakan oleh-oleh untuk kami, (b) Pupuk dikirim untuk para petani (2011: 136). Moreover, Ramlan (1980: 116) explains that the preposition untuk is used to indicate "functions" of something, as in (a) Sampah lain yang masih tersisa diproses menjadi kompos yang dapat dijual untuk pupuk

\section{Indonesian Preposition kepada}

According to Ramlan (1980: 77) the Indonesian preposition can be used as the following.

a) Kepada is used to indicate the "recipient", meaning that the recipient "receives" something form the "agent". For examples: Panggilan itu dilakukan dengan mengirimkan surat panggilan kepada pengusaha.

b) Kepada is used to indicate "something or someone which is intended to" For example: Saya sangat tertarik kepada pendidikan masyarakat.

c) Kepada is used to indicate the "object" For example: Orang tua itu sayang kepada anak-anaknya.

\section{Indonesian Preposition ke}

Chaer reveals that the Indonesian preposition $k e$ is used to reveal "the places where someone or something goes" which precedes before noun that indicates place, as in (a) Ibu pergi ke kantor pos, (b) Paman berangkat ke Surabaya, (c) Kami akan berdarmawisata ke Candi Borobudur (2011: 130). Another function of Indonesian preposition $k e$ is to say where something or someone moves, which precedes before "adverb of time" in a sentence, as in Dia pergi beristirahat ke Pulau Bali.

\section{Indonesian Preposition buat}

According to Chaer, the Indonesian preposition buat is used as the variant of Indonesian preposition untuk. Unfortunately, this Indonesian preposition is not recommended to use, for it has the same 
meaning to the Indonesian preposition untuk (2011: 137). For example: Ibu membawakan bunga buat kami.

\section{Indonesian Preposition bagi}

According to Ramlan (1980: 36), the Indonesian preposition bagi is used to indicate the term "intended", which is in line with the use of the Indonesian preposition untuk. For example: (a) Cabang-cabang produksi yang penting bagi Negara dan yang menguasai hidup orang banyak dikuasai Negara.

\section{Interlingual Transfer}

Interlingual transfer refers to the beginning or the early stages of learning a second language. Through the early stages, before the system of the second language is familiar to the second language learners, the native language is the only linguistic system in previous experience upon which the learner can draw (Brown, 1987: 177). The examples of interlingual transfer can be found when some English students tend to say 'sheep' for 'ship' or 'the book of Math' rather than 'Math's book'. These sentences refer to the negative inter-language transfer in learning English as a second language.

\section{Interference}

Another problem that often causes error in comprehending certain languages is interference. Interference is the first language influence on second language performance (Krashen, 1981: 64). He further explains that the first language influence may therefore be an indication of low acquisition (Kranshen, 1981; 67). In this case, interference becomes a problem on language acquisition for Indonesian learners in mastering English as a second language since the first language, which is Indonesian, may affect them.

Selinker (1971), Seligar (1988), and Ellis (1997) argue that in learning a target language, learners construct their own interim rules with the use of their first language knowledge, but only when they believe it will help them in the learning task or when they have become sufficiently proficient in the second language for transfer to be possible.

\section{Intralingual Transfer}

According to Delija and Koruti, intralingual error is the condition where errors occur due to partial learning of the target language (2013: 1). They add, as cited from Brown (1987), that intralingual refers to the overgeneralization error which involves the incorrect application of the previously learned second language material to a present second language context. They also mention that intralingual transfer can be attributed to the ignorance of rule restriction which according to Richards and Sampson means "applying rules to contexts to which they do not apply" (1974).

\section{The Students' Achievements in the Test}

As revealed previously, the data of this research is gathered by conducting a test to the sixth semester students of English department. The test aims to measure the mastery level of the use of prepositions for and to among the students. To determine the minimum passing score that the students should achieve in order to pass the test, the researcher refers to the academic regulation of Sanata Dharma University, in which 56\% would be considered to enter the category of sufficient (C). The students who achieve the score less than $56 \%$ of the highest score is considered to be in the category of insufficient. Meanwhile, grades' category of good (B) and very good (A) are determined by the researcher on the related material based on the score distribution, which is above the minimum passion score (56\%).

Since this research aims to figure out the students' mastery in applying English preposition for and to, a descriptive analysis presentation is required. The descriptive analysis provides the mean, median, range, mode, and standard deviation based on the students' final scores in the test. By providing these type of scores, the students' mastery in preposition for and to can be determined. The following table represents the descriptive analysis of the test. 


\begin{tabular}{|c|c|c|}
\hline No & Variables & Score \\
\hline 1 & Mean & 23 \\
\hline 2 & Median & 23 \\
\hline 3 & Range & 14 \\
\hline 4 & Mode & 23 \\
\hline
\end{tabular}

After dealing with the descriptive analysis, then the score category applied to this study is determined. The highest score that the students could achieve throughout the test is 30 . Thus, the $56 \%$ of this highest score is 19. It reveals that this score is the minimum passing score to be considered in the sufficient category. Meanwhile, the students who achieve the score less than the minimum passing score (19) are considered to be in the insufficient category and automatically fail the test. The score category is provided below:

\begin{tabular}{|c|c|}
\hline Score & Category \\
\hline $27-30$ & Very good \\
\hline $23-26$ & Good \\
\hline $19-22$ & Sufficient \\
\hline $15-18$ & Insufficient \\
\hline$\leq 14$ & Fail \\
\hline
\end{tabular}

According to the students' final score, the mean of the students' score is $23(73,06 \%)$. Considering the category above, it can be summed up that the students' accuracy level in mastering prepositions for and to reaches the category of good. The table provided below displays the students' achievement in the test according to the category above.

\begin{tabular}{|c|c|c|c|}
\hline Score & Category & $\begin{array}{c}\text { Number of Students } \\
\text { achieving the category }\end{array}$ & Percentage \\
\hline $27-30$ & Very Good & 8 & $16,33 \%$ \\
\hline $23-26$ & Good & 18 & $36,73 \%$ \\
\hline $19-22$ & Sufficient & 15 & $30,61 \%$ \\
\hline $15-18$ & Insufficient & 8 & $16,33 \%$ \\
\hline$\leq 14$ & Fail & 0 & $0 \%$ \\
\hline
\end{tabular}

Regarding the table above, it can be concluded that most of the students (18) students $(36,73 \%)$ reach the good category. Whereas there are eight students (16,33\%) enter the category of very good. Meanwhile, there are fifteen students $(30,61 \%)$ reach the category of sufficient, and the rest of the total students (8) enter the category of insufficient $(16,33 \%)$. It also can be concluded that there is none of the students who are in the category of fail.

\section{The Students' Difficulties in Mastering prepositions for}

Although the students' achievements in the test enters the category of good, it is undeniable that most of them still find difficulties in mastering the prepositions for. It is proven by the mistakes or errors produced by the students during the test.

The errors produced in this analysis are categorized as syntax errors. It is because the errors deal with the grammatical function of prepositions for in order to form a correct and well-performed sentence. Besides, the errors also occur due to the ignorance of rules of preposition for. To make a better view of the syntax errors of preposition for, the table is displayed as follows. 


\begin{tabular}{|c|c|c|c|}
\hline Part & $\begin{array}{l}\text { Item } \\
\text { Number }\end{array}$ & Incorrect Sentences & Correct Sentences \\
\hline \multirow{11}{*}{$\mathbf{A}$} & 3 & They are eager to revenge. & They are eager for revenge. \\
\hline & 5 & $\begin{array}{l}\text { We had been talking to a } \\
\text { good half hour. }\end{array}$ & We had been talking for a good half hour. \\
\hline & 6 & $\begin{array}{l}\text { Shaking your head to "NO" is } \\
\text { not universal. }\end{array}$ & $\begin{array}{l}\text { Shaking your head for "NO" is not } \\
\text { universal. }\end{array}$ \\
\hline & 8 & $\begin{array}{l}\text { l've applied to a job at the } \\
\text { factory, I don't know if I'll get it. }\end{array}$ & $\begin{array}{l}\text { l've applied for a job at the factory, I don't } \\
\text { know if l'll get it. }\end{array}$ \\
\hline & 12 & $\begin{array}{l}\text { Paisley claims to speak to the } \\
\text { majority of local people. }\end{array}$ & $\begin{array}{l}\text { Paisley claims to speak for the majority of } \\
\text { local people. }\end{array}$ \\
\hline & 14 & $\begin{array}{l}\text { What's the proper word to } \\
\text { those things? }\end{array}$ & What's the proper word for those things? \\
\hline & 15 & $\begin{array}{l}\text { That's too much responsibility to } \\
\text { a child. }\end{array}$ & That's too much responsibility for a child. \\
\hline & 16 & $\begin{array}{l}\text { Tomorrow morning I have to } \\
\text { catch a plane. I'm leaving my } \\
\text { house to the airport at } 7.30 \text {. }\end{array}$ & $\begin{array}{l}\text { Tomorrow morning I have to catch a plane. } \\
\text { I'm leaving my house for the airport at } 7.30 \text {. }\end{array}$ \\
\hline & 17 & Let me carry that bag to you. & Let me carry that bag for you. \\
\hline & 18 & We're invited to 7.30 . & We're invited for 7.30 . \\
\hline & 19 & $\begin{array}{l}\text { To her to have survived such an } \\
\text { ordeal is remarkable. }\end{array}$ & $\begin{array}{l}\text { For her to have survived such an ordeal is } \\
\text { remarkable. }\end{array}$ \\
\hline Part & $\begin{array}{c}\text { Item } \\
\text { Number }\end{array}$ & Incorrect Sentences & Correct Sentences \\
\hline \multirow{3}{*}{ B } & 3 & He plays to Denver. & He plays for Denver. \\
\hline & 4 & I am delighted to you. & I am delighted for you. \\
\hline & 5 & $\begin{array}{l}\text { The editor is the person who is } \\
\text { responsible to what appears in } \\
\text { a newspaper. }\end{array}$ & $\begin{array}{l}\text { The editor is the person who is responsible } \\
\text { for what appears in a newspaper. }\end{array}$ \\
\hline
\end{tabular}

According to the table above, it can be summed up that the errors are caused by the incorrect application of preposition for. These errors occur when they deal with several functions of preposition for in order to build a well-performed sentence such as: to obtain something, to show length of time, to reveal a meaning of something, to show who is employed (by), to represent someone/something, to consider what can be expected from somebody/something, to show where somebody/something is going, to help someone, to show that something is arrange or intended to happen at particular time, to express how difficult or pleasant something is that somebody might do or has done, and to show someone' better feeling of something/someone else. One of the incorrect sentence that the students made during the test is Tomorrow morning I have to catch a plane. I'm leaving my house the airport at 7.30.

There are only six students $(12 \%)$ from the total students (49) who ansared this item correctly. Whereas most of the students, which are 43 students, ansared the question incorrectly. It can be concluded that the students' achievement through this item is very low since the percentage of the total 
incorrect answers reaches 88\%. The incorrect sentence that most of the students have made is: Tomorrow morning I have to catch a plane. I'm leaving my house to the airport at 7.30. Most of the students might consider the preposition to in this sentence is the appropriate one to apply before the object "the airport" as the destination of the subject. Since they might consider the object "the airport" is the "endpoint of destination", therefore they apply preposition to. However, this is incorrect because "the airport" here discusses an intention rather than movement (Lindstromberg, 2010: 226).

This also refers to one the function of preposition for, in which it is used to show where somebody/something is going. Therefore, the correct answer must be: Tomorrow morning I have to catch a plane. I'm leaving my house for the airport at 7.30.

It is clearly seen in the sentence that, before the indirect object "my house" there is a travel-related word "leaving" which is typically associated with preposition for. It is true that this travel-related word does indicate that the landmark (airport) is a destination. Yet, in this case, for does not focus on the endpoint of destination (like to does) but rather an intention in some early or intermediate stage of the trip (Lindstromberg, 2010: 226).

\section{The Students' Difficulties in Mastering prepositions to}

As revealed in the previous explanation, the errors produced by the students are considered as syntax errors because it deals with the grammatical function of prepositions to in order to form a correct and wellperformed sentence. Furthermore, the errors also occur due to the ignorance of rules of preposition to. To make a better view of the syntax errors of preposition to, the table is displayed below.

\begin{tabular}{|c|c|c|c|}
\hline Part & $\begin{array}{l}\text { Item } \\
\text { Number }\end{array}$ & Incorrect Sentences & Correct Sentences \\
\hline \multirow{10}{*}{$\mathbf{A}$} & 1 & $\begin{array}{l}\text { The vegetables are cooked for } \\
\text { perfection. }\end{array}$ & The vegetables are cooked to perfection. \\
\hline & 4 & $\begin{array}{l}\text { Attach a recent photograph for } \\
\text { your application form. }\end{array}$ & $\begin{array}{l}\text { Attach a recent photograph to your } \\
\text { application form. }\end{array}$ \\
\hline & 7 & $\begin{array}{l}\text { Does your interest in nuclear } \\
\text { physics extend for nuclear } \\
\text { weaponry? }\end{array}$ & $\begin{array}{l}\text { Does your interest in nuclear physics } \\
\text { extend to nuclear weaponry? }\end{array}$ \\
\hline & 9 & $\begin{array}{l}\text { Offices handling everything from } \\
\text { espionage for assassination. }\end{array}$ & $\begin{array}{l}\text { Offices handling everything from } \\
\text { espionage to assassination. }\end{array}$ \\
\hline & 10 & $\begin{array}{l}\text { I woke for the sound of torrential } \\
\text { rain. }\end{array}$ & I woke to the sound of torrential rain. \\
\hline & 11 & For her astonishment, he smiled. & To her astonishment, he smiled. \\
\hline & 13 & $\begin{array}{l}\text { There will be a visit for the } \\
\text { theater. }\end{array}$ & There will be a visit to the theater. \\
\hline & 21 & The letter reduced her for tears. & The letter reduced her totears. \\
\hline & 22 & $\begin{array}{l}\text { Colleges of education may have } \\
\text { anything from a few hundred for } \\
\text { nearly } 2000 \text { students. }\end{array}$ & $\begin{array}{l}\text { Colleges of education may have } \\
\text { anything from a few hundred to nearly } \\
2000 \text { students. }\end{array}$ \\
\hline & 23 & $\begin{array}{l}\text { She is always wonderfully kind } \\
\text { for me. }\end{array}$ & She is always wonderfully kind to me. \\
\hline \multirow{4}{*}{ B } & 1 & $\begin{array}{l}\text { There will be a solution for this } \\
\text { problem. }\end{array}$ & There will be a solution to this problem. \\
\hline & 2 & It is a threat for world peace. & It is a threat to world peace. \\
\hline & 6 & How long is it for lunch? & How long is it to lunch? \\
\hline & 7 & $\begin{array}{l}\text { He woke for the sound of pouring } \\
\text { rain. }\end{array}$ & He woke to the sound of pouring rain. \\
\hline
\end{tabular}


According to the table above, it can be concluded that the errors caused by incorrect application of preposition to occur when it deals with several grammatical functions of preposition to in order to build a wellperformed sentence such as: to reach a particular state/condition, to show two things are attached or connected, to indicate something that is "as far as something", to show the end or limit of a range or period of time, to indicate that something happens while something else is happening or being done, to show somebody's attitude or reaction to something, to show direction towards something, to show the person or thing that receives something, to show something that is directed towards something/somebody or concerning something/somebody, and to indicate something before the start of something.

One of the incorrect sentence that the students made during the test is astonishment, he smiled. her

There are only 16 students (33\%) who ansared the question correctly. On the other hand, most of the students, which are 33 (67\%), ansared the question incorrectly. It can be assumed that the students' understanding in using preposition to in this item is low since just few of them could answer the item correctly. The incorrect answer that most of the students made in the test is: For her astonishment, he smiled.

Throughout this sentence, the students might not comprehend the distinction between the use of preposition for and to if both prepositions are applied in a sentence. Consequently, they just put the preposition for arbitrarily.

This sentence actually indicates someone's attitude towards something. In this case, the subject "he" smiled towards someone's astonishment. Thus, this sentence needs a preposition to indicate that someone gives a reaction towards something, which is preposition to. The application of to here is to show somebody's attitude or reaction to something. Then, the correct answer is: To her astonishment, he smiled.

The Errors that Contribute to the Students' Mastery of Prepositions for and to

Referring to the analysis that has been done previously, the researcher figures out three types of errors that contribute to the students' mastery of preposition for and to, which are interlingual transfer, interference, and intralingual transfer. The percentages of each errors are displayed in the table as follows.

\begin{tabular}{|c|c|c|}
\hline Types of Errors & Total Number of Questions & Percentage \\
\hline Interlingual & 20 & $64,5 \%$ \\
\hline Interference & 7 & $22,6 \%$ \\
\hline Intralingual & 4 & $12,9 \%$ \\
\hline
\end{tabular}

According to the table, the biggest errors that contribute to the students' mastery of preposition for and to is interlingual transfer. The researcher figures out that $64,5 \%$ of the total questions of the test (20 questions) produce errors caused by interlingual transfer among the students. Secondly, another type of errors that contribute to the students' mastery of preposition for and to is interference. The percentage of errors caused by interference in the test is $22,6 \%$, in which there are 7 questions (all question of part B) causing students' errors in the test. Finally, intralingual error also contributes to the students' mastery of preposition for and to. There are 4 questions $(12,9 \%)$ in the test that contribute to the students' errors caused by intralingual transfer.

\section{The Interlingual Error}

The first type of errors that contributes to the students' mastery on prepositions for and to is interlingual transfer. The 
interlingual transfer occurs because the students might think that the prepositions for and to share the same meaning and they are exchangeable. Consequently, they just apply random prepositions without considering the function of each prepositions and the meaning of the sentence.

One of the questions that contributes to the interlingual errors is Let me carry that bag you. In this item number, the students face difficulties to differentiate the prepositions for and to and decide the correct one that suits the sentence. They then apply random preposition and as a result, there are many mistakes made by the students.

As stated in the previous analysis, based on the Oxford Advanced Learner's Dictionary 8th Edition, the application of for in this item number is to help someone/something. In this sentence, the preposition for indicates the subject "me" who tries to help the object by carrying his/her bag. Therefore, the correct answer would be: Let me carry that bag for you.

\section{Interference Errors}

The second type of errors is interference. Regarding the analysis of the test, the interference happens when the students want to choose the correct English translation in the test (Part B). In this part, they are required to choose the correct English sentence containing Indonesian prepositions. As a result, the students faced the difficulties when they wanted to translate the Indonesian preposition pada, untuk, bagi into English preposition for and to, for in Indonesian language, pada, untuk, bagi almost share the same meaning.

One example that contributes to the interference error in the test is when the students want to choose the correct translation of the Indonesian sentence Akan adasebuahsolusiuntukmasalahini into English sentence. The correct answer is "There will be a solution to this problem." In this part, the interference error happens when the rules of Indonesian sentence influence them to decide which preposition (to or for) can means untuk. In this case, the students may consider both prepositions can be applied as the translation of Indonesian preposition untuk. In fact, the application of for in this item is incorrect because if we consider the meaning of the sentence, the appropriate preposition to use is to, for it indicates how things are related or connected each other (Merriam Webster, 2008: 1731).

\section{Intralingual Transfer}

The third type of errors is intralingual transfer. Intralingual transfer can be attributed to the ignorance of rule restriction which means "applying rules to contexts to which they do not apply". Referring to the analysis, it can be revealed that the intralingual errors occurs when students are lack of knowledge about prepositions for and to and they seems to ignore the functions of each preposition.

One of the item numbers that is caused by intralingual transfer in the test is Paisley claims to speak the majority of local people.

The sentence above may be quite confusing since half of the students are unable to differentiate the use of preposition for and to. In fact, the use of both prepositions in this sentence is dissimilar. The students then may face two different answers, which are "Paisley claims to speak for the majority of local people" and "Paisley claims to speak to the majority of local people." In this case, the students might be confused to decide which preposition they have to put before the noun phrase "the majority of local people". The sentence which uses preposition for indicates the subject "Paisley" as a representative of the majority of local people; "Paisley" represents someone who (maybe) part of the local people. Conversely, when preposition to is applied, it points out the subject "Paisley" as the one who (claims to) speaks to the majority of local people. According to the meaning of the sentence, the correct preposition is for since the subject "Paisley" is indicated as the representative of the majority of local people. Thus, the correct sentence must be: Paisley claims to speak for the majority of local people. 
Referring to the Oxford Advanced Learner's Dictionary 8th Edition, this sentence uses one of the functions of preposition for, in which preposition for is used as a representative (of something/someone).

\section{Conclusion}

It is figured out that the sixth semester students at English Letters Department of Sanata Dharma University mastery on the prepositions for and to enters the category of good. Their average score (mean) is 23 $(73,06 \%)$, which is above the target of minimum score (56\%). Although the students' achievement throughout this preposition is quite good and above the target of minimum score $(56 \%)$, it can be seen that there are many errors made during the test.

In this research, it is found out that the errors caused by the incorrect application of prepositions for and to are categorized as syntax errors. It is because the errors deal with the grammatical functions of prepositions for and to in order to form a correct and well-performed sentence. Besides, the errors also occur due to the ignorance of rules of prepositions for and to.

The students' errors in mastering the prepositions for and to are influenced by several types of errors, which are interlingual transfer, interference, and intralingual transfer.

\section{References}

Brown, H. Douglas. Principles of Language Learning and Teaching. New Jersey: Prentice Hall Inc., 1987.

Chaer, Abdul. Tata Bahasa Praktis Bahasa Indonesia. Jakarta: PT. Rineka Citra, 1947.
Close, R. A., A Reference Grammar for Students of English. London: Longman Group, Ltd, 1975.

Delija, Shpresa and Ogerta Koruti. Challenges in Teaching Prepositions in a Language Classroom. Journal of Education and Practice. Vol.4, No.13, 2013. October 1, 2015.

Guralnik, David B. Webster's New World Dictionary of the American Language. Second College Edition. New York: Simon and Schuster, 1986.

Hornby, A.S. Oxford Advanced Learner's Dictionary (8 $8^{\text {th }}$ Edition). Oxford: Oxford University Press, 2010.

Krashen, Stephen. Second Language Acquisition and Second Language Learning. New York: Pergamon Press, 1981.

Lindstromberg, Seth. English Preposition Explained Revised Edition. Amsterdam: John Benjamins Publishing Company, 2010.

Merriam-Webster's Advanced Learner's Dictionary. USA: Merriam-Webster, Inc, 2008.

Murcia, Marianne Celce and Diane LarsenFreeman. The Grammar Book. United State of America: Heinle and Heinle Publishers, 1999.

Ramlan, M. Kata Depan atau Preposisi dalam Bahasa Indonesia. Yogyakarta: UP. Karyono, 1980. 